\title{
Emotional and behavioral problems and associated factors among children and adolescents on highly active anti-retroviral therapy in public hospitals of West Gojjam zone, Amhara regional state of Ethiopia, 2018: a cross-sectional study
}

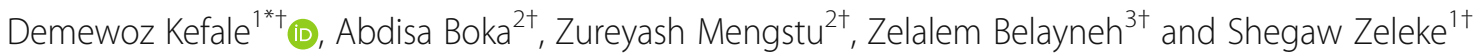

\begin{abstract}
Background: Children and adolescents with HIV/AIDS are more likely to have emotional and behavioral problems than the general population. This can result in a continuing negative influence on the quality of life, school performance, immunity and co-morbidity of children and adolescents with HIV/AIDS.

Objective: To assess the prevalence and associated factors of Emotional and Behavioral Problems among children and adolescents on Highly Active Anti-Retroviral Therapy in the public hospitals of West Gojjam Zone, Amhara regional state of Ethiopia.

Methods: An institutional based cross sectional study was conducted by screening 411 children and adolescents for emotional and behavioral problems using Pediatric Symptomatology Check List (PSCL). Systematic random sampling technique was used to select the study participants. Data analysis was done using SPSS version 23. Bivariable and multivariable logistic regression analysis were fitted to identify factors associated with Emotional and Behavioral Problems. Odds ratio (OR) with 95\% confidence interval (Cl) was computed to determine the level of significance.

Result: Out of the total 411 participants, 43.6\% were screened positive for Emotional and Behavioral Problems. Lower age (AOR = 5.33, 95\%Cl: 2.56-11.04), having non-kin care giver ( $\mathrm{AOR}=4.64,95 \% \mathrm{Cl}: 1.20-17.90)$, parental loss ( $\mathrm{AOR}=2.15$, 95\%Cl: 1.03-4.49), non self-disclosure of HIV sero status (AOR $=1.99,95 \%$ Cl: 1.16-3.41) and having distressed care giver ( $\mathrm{AOR}=1.64,95 \% \mathrm{Cl}: 1.04-2.57$ ) had statistically significant association with EBPs.

Conclusion: The prevalence of Emotional and Behavioral Problems is high among children and adolescents on HAART. Lower age, care giver's mental distress, non-self disclosure status, having non-kin care giver and parental loss were variables significantly associated with EBPs. This demonstrates a need for the integration of Mental Health and Psycho Social Support (MHPSS) service with HIV/AIDS care.
\end{abstract}

Keywords: Behavioral and emotional problems, Pediatric symptomatology check list, Children and adolescent, HIV/AIDS and mental health, West Gojjam

\footnotetext{
* Correspondence: demewozk@yahoo.com

${ }^{\dagger}$ Demewoz Kefale, Abdisa Boka, Zureyash Mengstu, Zelalem Belayneh and

Shegaw Zeleke contributed equally to this work.

'Department of Pediatrics and Child Health Nursing, College of Health

Science, Debre Tabor University, Debre Tabor, Ethiopia

Full list of author information is available at the end of the article
}

(c) The Author(s). 2019 Open Access This article is distributed under the terms of the Creative Commons Attribution 4.0 International License (http://creativecommons.org/licenses/by/4.0/), which permits unrestricted use, distribution, and reproduction in any medium, provided you give appropriate credit to the original author(s) and the source, provide a link to the Creative Commons license, and indicate if changes were made. The Creative Commons Public Domain Dedication waiver (http://creativecommons.org/publicdomain/zero/1.0/) applies to the data made available in this article, unless otherwise stated. 


\section{Background}

Globally, more than 3.4 million children and adolescents are living with HIV or died due to AIDS related cases [1]. Additionally, an estimated 29 adolescents acquired HIV every hour. Childhood and adolescence is the only age group in which AIDS-related deaths are not decreasing [2] as being adolescent by itself is a risk for the vulnerability of HIV infection [3]. Chronic illness such as HIV/AIDS often represents a traumatic change in the life of children and adolescents which significantly affects their health, welfare, social, mental and economic development [4].

There is a world wide effort to provide sustainable antiretroviral medication to prolong life and to reduce stigma. This calls a more holistic and comprehensive approach to HIV care and treatment $[5,6]$. However, HIV treatment outcome of children and adolescents has not yet been satisfactory [7] due to the co-morbidity [8] and un usual onset of Emotional and Behavioral Problems (EBPs) [9].

Health related factors clearly play a role in emotional and behavioral problems. HIV is an illness that affects emotions and behaviors of children and adolescents [1012]. This can accelerate AIDS-related mortality among HIV-positive children and adolescents regardless of the scale up of antiretroviral therapy innovations [13-15]. It can also have diverse and devastating consequences like suicidal ideation and attempt, school absenteeism and high drop-out rates, high rates of grade retention, engagement in risky behavior and being hyperactive (16), and may progress to other primary psychiatric disorders like conduct disorder, antisocial personality disorder, anxiety, depression and others [12].

It is also recommended that HIV/AIDS care service is expected to have a holistic approach applicable to all children and adolescents affected by AIDS in all settings $[16,17]$. In contrast to this, health-care systems in low income and middle income countries have not adequately addressed the identification and interventions of EBPs in children and adolescents with AIDS. Moreover, the focus of most other studies was on adults' health and little emphasis is given for children and adolescent's health [18-20]. The low level of awareness about emotional and behavioral symptoms [21], the unusual nature of the symptoms, the wide spread traditional explanatory models and preference of traditional treatment options might have significant challenges upon the utilization of mental health and psychosocial support services for children and adolescents with HIV/AIDS [22].

Although there is a study done in Ethiopia reporting about the EBPs of children and adolescents on HAART, it is limited to Addis Ababa (the capital city of Ethiopia), and did not address the other parts of Ethiopia [23]. This sounds a need to assess the EBPs of children and adolescents in rural parts of Ethiopia which have different cultural context and living standards from Addis Ababa.

\section{Methods \\ Study design, period and setting}

An institutional based cross-sectional study was conducted in West Gojjam zone public hospitals from March 30/2018 to May30/2018. West Gojjam zone is found in Amhara Region States of Ethiopia and its zonal city is Finote Selam which is found $330 \mathrm{~km}$ North West from Addis Ababa. The zone has 6 public hospitals and only five of them provide ART service for about 3, 214 children and adolescents.

\section{Sample size calculation and sampling procedure}

The assumptions made for sample size calculation were a 95\% confidence interval, and 50\% expected prevalence EBPs to get the maximum sample size and a $5 \%$ margin of error. By adding a $10 \%$ non-response rate, the total sample size was 423. Systematic random sampling was employed to select the study participants. Initially, the total expected number of children and adolescents attending ART clinic during the study period was calculated from the records of each hospital. Then, the number of children and adolescents included in each hospital was determined based on the proportionate population size. The sampling interval (K) was determined by dividing the total number of children and adolescents on HAART in each hospital to the sample size to be drawn from that hospital. Lottery method was used to select the first participant between one and K. Subsequently, $K$ value was added until the sample size allocated to each hospital was reached.

\section{Data collection instrument and techniques}

An interviewer administered questionnaire was used for the data collection (Additional file 1). The questionnaire was prepared in English and translated in to Amharic (the commonly spoken language in the study area), and finally back to English to test the accuracy of translation. The Amharic version questionnaire was pre-tested on 22 (5\%) of children and adolescents on HAART at Felegehiwot Hospital (not included in the study). The questionnaire had five parts including sociodemographic characteristics, clinical related factors, caregiver related factors, Pediatric Symptomatology Check list (PSCL) and Self Reporting Questionnaire (SRQ-20).

Parents/care givers of children and adolescents who fulfilled the inclusion criteria (age range of 5-18 years, having at least for 1 month follow up and never been admitted at inpatient care) were requested to give assent on the behalf of their child or adolescent after brief explanation about the scope and objectives of the study. 
The PSCL was used to screen Emotional and Behavioral Problems among children and adolescents on HAART. It is a tool validated to assess emotional and behavioral problems in children and adolescents with HIV infection and other chronic diseases [24-26]. PSCL consists of a set of 35 questions with three possible responses rated as never (0), sometimes (1), often (2).. The total score was calculated by adding together the scores for each of the 35 questions and had a range scores from 0 to 70 . A cut off point of 24 and above for age 5-6 years and 28 and higher for age $>6$ years were taken to indicate EBPs [27]. The symptoms of PSCL was translated and modified in a culturally acceptable way.

Care givers' mental distress was measured using WHO's Self Reporting Questionnaire (SRQ-20) assessment tool [28]. SRQ has 20 "Yes" or "No" questions with a total scores of 0 to 20. A score of 7 and above was considered as a cutoff point of having mental distress [10].

The data was collected by eight BSc (Bachelor of Science) level health professionals with the supervision of two MSC health professionals after two consecutive days of training. During the interview, caregivers were also participated to answer some questions when the child had difficulty of answering questions adequately. Finally, some clinical related data were extracted from the hospital records.

\section{Operational definition}

Non self-disclosure of HIV sero status: is defined as the child or adolescent who were not aware of his/her HIV positive sero-status status because the professional or the care giver did not inform as he/she is HIV sero-positive.

\section{Data analysis and interpretation}

The collected data were checked for its completeness and consistency. Then, it was coded and entered in to the computer using EP-data version 4.2software and transformed in to SPSS version 23 for analysis. Descriptive statistics was carried out to measure the magnitude and distributions of EBP and the result was presented using text and tables. Both bivariable and multivariable logistic regression analysis were fitted to identify factors associated with emotional and behavioral problems. Variables with a $P$-value of less than 0.25 in the bivariable analysis were transformed into the multivariable analysis. In multivariable analysis, variables with a $p$-value of less than 0.05 were considered statistically significant. Adjusted odds ratio (AOR) with the corresponding 95\% confidence interval $(\mathrm{CI})$ was used to show the strength of association.

\section{Results}

Socio-demographic characteristics of children and adolescents on HAART in public hospitals of west Gojjam zone

A total of 411 respondents participated in the study with a response rate $97.2 \%$. The mean age $( \pm S D)$ of respondent was $11.67( \pm 3.25)$ years. More than half, (59.9\%), of them were males. Regarding their residency, $67.2 \%$ were from urban. (Table 1).

\section{Clinical related characteristics}

About 84.4\% were on ART treatment for more than 6 months duration, and $70.1 \%$ knew their HIV status (Table 2).

\section{Care-giver related characteristics}

Almost half, $48.7 \%(n=200)$, of the care givers of children and adolescents were College/Higher educational level and $83.0 \%(n=341)$, of care-givers were child's own parents. About $44.0 \%(n=181)$, had single parental loss which mean that either father or mother is died. Most, 79.3\% $(n=326)$, of care givers of children and adolescents had positive HIV sero- status. Additionally, about $41.8 \%$ of the care givers were screened positive for mental distress.

\section{Distributions of symptoms of behavioral and emotional problems}

"Seems to be having less fun" and "School grades dropping" are the most commonly displayed symptom

Table 1 Socio-demographic characteristics of children and adolescents on HAART in West Gojjam Zone Public Hospitals, North West Ethiopia, 2018( $N=411)$

\begin{tabular}{llll}
\hline Variables & Categories & Frequency & Percentage \\
\hline Ages (in years) & $5-9$ & 110 & 26.8 \\
Sex & $10-14$ & 211 & 51.3 \\
& Male & 246 & 59.9 \\
Religion & Female & 165 & 40.1 \\
& Orthodox & 352 & 85.6 \\
Residency & Protestant & 42 & 10.2 \\
School attendance & Muslim & 17 & 4.1 \\
Family size & Urban & 276 & 67.2 \\
& Rural & 135 & 32.8 \\
& Yes & 335 & 81.5 \\
Family monthly income & No & 76 & 18.5 \\
& 1-3 & 232 & 56.4 \\
& 4-6 & 156 & 38.0 \\
& $>1660.34$ & 165 & 5.6 \\
\hline
\end{tabular}

Abbreviations: HAART Highly Active Anti Retroviral Therapy 
Table 2 Clinical related characteristics of children and adolescents on HAART in West Gojjam Zone Public Hospitals, North West Ethiopia, 2018, $(N=411)$

\begin{tabular}{|c|c|c|c|}
\hline Variables & Categories & Frequency & Percentage \\
\hline \multirow[t]{2}{*}{ Duration of ART treatment } & $1-6$ months & 64 & 15.6 \\
\hline & $>6$ months & 347 & 84.4 \\
\hline \multirow[t]{2}{*}{ Self Disclosure of HIV sero-status } & Disclosed & 288 & 70.1 \\
\hline & Not disclosed & 123 & 29.9 \\
\hline \multirow[t]{4}{*}{ Recent CD4 count } & $<200$ cells $/ \mathrm{mm}^{3}$ & 6 & 1.5 \\
\hline & 200-349 cells $/ \mathrm{mm}^{3}$ & 29 & 7.1 \\
\hline & $350-500$ cells $/ \mathrm{mm}^{3}$ & 66 & 16.1 \\
\hline & $>500$ cells $/ \mathrm{mm}^{3}$ & 310 & 75.4 \\
\hline
\end{tabular}

Abbreviations: HAART Highly Active Anti Retroviral Therapy

endorsed by 31.1 and $29.8 \%$ of children and adolescents on HAART, respectively However "Acts as if driven by a motor" and "Takes unnecessary risks" are the least commonly symptoms mentioned by $0.8 \%$ of the respondents (Table 3).

\section{Prevalence and factors associated with emotional and behavioral problems}

Out of the total 411 children and adolescents participated in the study, $43.6 \%(N=179)$ were screened positive for EBPs with $\mathrm{CI}=(38.8-48.4)$. Bivariable and multivariable logistics analysis were computed to identify factors associated with EBPs. In the multivariable logistic analysis, age ranges of 5-9 years, parental loss, non-self disclosure to HIV-Positive sero status, having non kin care-givers and care giver's mental distress had statically significant association with EBPs (Table 4).

\section{Discussion}

Findings of the current study showed that the prevalence of emotional and behavioral problems among children and adolescents on HAART in West Gojjam Zone public hospitals was $43.6 \%$ with $\mathrm{CI}=(38.8-48.4)$. This finding is in line other similar studies of India (40\%) [29] and Ethiopia (39.3\%) [23]. However, it shows a lower result than a study conducted in Uganda (58.5\%) [30]. This might be due to the difference of screening tools used $[10,11]$. But it was higher than a study conducted in USA (7.4\%) [31], India (30\%) [11, 27] and Portugal (26.7\%) [32]. This variation might be explained due to the fact that there is a great difference in the socioeconomical, health care delivery system and cultural context of the study subjects $[7,33]$.

The findings of the current study showed a higher prevalence of EBPs than other similar studies done in Ambo district (17.7\%) [34] and Butajira district (6.5\%) [35] among non-HIV infected children. This clearly showed that the prevalence of emotional and behavioral problems among children and adolescents with HIV/ AIDS is higher than similar groups in the general population. This higher prevalence might be due to direct viral effects on the brain, poor self-esteem, stigma and discrimination [36] and pill burdens [37] of children and adolescents with HIV/AIDS. The odds of developing emotional and behavioral problems among children and adolescents who were not aware of their HIV sero positive status was 1.99 times (AOR $=1.99,95 \% \mathrm{CI}: 1.16$, 3.41) higher than children and adolescents who were aware their HIV sero positive status. This is consistent with other similar studies done in Malawi [19] and South Africa [3] and reported by WHO [38]. This could be due to the fact that children and adolescents who did not recognize their HIV sero positive status may have confusion/tension why they have to continue to take drugs every day and maintain false understanding/perception of the illness [38].

The odds of having emotional and behavioral problems among children and adolescents who had non-kin care givers was 4.64 times $(\mathrm{AOR}=4.64,95 \% \mathrm{CI}$ : 1.20 17.90) higher as compared children and adolescents whose care givers are child's own parents. This idea is consistent with previous studies of USA [39],Thailand [40], India [27], South Nigeria [22] and Kenya) [41]. The possible explanation might be child's own parents can provide a more protective and parenthood care than non-kin care givers, and children and adolescents can have good attachment with individuals whom they attached to earlier [18].

Similarly, children and adolescents who had lost both parents had 2.15times increased odds of having emotional and behavioral problems as compared to children and adolescents whose parents are alive. This idea is similar with study done in Malawi [19], South Africa [3, 42], Nigeria [22] and Kenya [41]. The possible reason might be due to the difficulty of children and adolescents to adapt themselves to live without parents which may pose them to a prolonged mental and behavioral problems [8].

Studies from different parts of the world (USA [39, 43], London UK [44], and South Africa [42]) identified 
Table 3 Distributions of Pediatrics Symptomatic Check List items among children and adolescents on HAART in West Gojjam Zone Public Hospitals, North West Ethiopia, $2018(N=411)$

\begin{tabular}{|c|c|c|c|}
\hline \multirow[t]{2}{*}{ Symptoms } & \multicolumn{3}{|l|}{ Responses } \\
\hline & Never(0) N/\% & Sometimes(1)N/\% & Often(2)N/\% \\
\hline Complains of aches and pains & $315 / 76.6 \%$ & $37 / 9 \%$ & $59 / 14.4 \%$ \\
\hline Spends more time alone & $359 / 87.3 \%$ & $29 / 7 \%$ & $23 / 5.7 \%$ \\
\hline Tires easily, has little energy & $341 / 83 \%$ & $57 / 13.8 \%$ & $13 / 3.2 \%$ \\
\hline Fidgety, unable to sit still & $318 / 77.4 \%$ & $35 / 8.5 \%$ & $58 / 14.1 \%$ \\
\hline Has trouble with teacher & $309 / 75.1 \%$ & $67 / 16.3 \%$ & $35 / 8.6 \%$ \\
\hline Less interested in school & $293 / 71.2 \%$ & $89 / 21.6 \%$ & $29 / 7.2 \%$ \\
\hline Acts as if driven by a motor & $397 / 96.5 \%$ & $11 / 2.7 \%$ & $3 / 0.8 \% \%$ \\
\hline Daydreams to much & $380 / 92.4 \%$ & $20 / 4.8 \%$ & $11 / 2.8 \%$ \\
\hline Distracted easily & $243 / 59.1 \%$ & $112 / 27.2 \%$ & $56 / 13.7 \%$ \\
\hline Is afraid of new situations & $293 / 71.2 \%$ & $95 / 23.1 \%$ & $23 / 5.7 \%$ \\
\hline Feels sad, unhappy & $225 / 54.7 \%$ & $125 / 30.4 \%$ & $61 / 14.9 \%$ \\
\hline Is irritable, angry & $215 / 52.3 \%$ & $84 / 20.4 \%$ & $112 / 27.3 \%$ \\
\hline Feels hopeless & $345 / 83.9 \%$ & $34 / 8.2 \%$ & $32 / 7.9 \%$ \\
\hline Has trouble concentrating & $276 / 67.1 \%$ & $54 / 13.1 \%$ & $81 / 19.8 \%$ \\
\hline Less interested in friends & $338 / 82.2 \%$ & $17 / 4.1 \%$ & $56 / 13.8 \%$ \\
\hline Fights with other children & $189 / 45.9 \%$ & $151 / 36.7 \%$ & $71 / 17.4 \%$ \\
\hline Absent from school & $316 / 76.8$ & $53 / 12.8 \%$ & $42 / 10.4 \%$ \\
\hline School grades dropping & $32 / 7.7 \%$ & $257 / 62.5 \%$ & $122 / 29.8 \%$ \\
\hline Is down on him or herself & $376 / 91.4 \%$ & $23 / 5.6 \%$ & $12 / 3 \%$ \\
\hline Visits the doctor with nothing wrong & $284 / 69 \%$ & $51 / 12.4 \%$ & $76 / 18.6 \%$ \\
\hline Has trouble sleeping & $300 / 72.9 \%$ & $72 / 17.5 \%$ & $39 / 9.6 \%$ \\
\hline Worries a lot & $379 / 92.2 \%$ & $21 / 5.1 \%$ & $11 / 2.7 \%$ \\
\hline Wants to be with you more than before & $372 / 90.5 \%$ & $9 / 2.1 \%$ & $30 / 8.4 \%$ \\
\hline Feels he or she is bad & $359 / 87.3 \%$ & $23 / 5.5 \%$ & $29 / 7.2 \%$ \\
\hline Takes unnecessary risks & $401 / 97.5 \%$ & $7 / 1.7 \%$ & $3 / 0.8 \%$ \\
\hline Gets hurt frequently & $334 / 81.2 \%$ & $26 / 6.3 \%$ & $51 / 12.5 \%$ \\
\hline Seems to be having less fun & $121 / 29.4 \%$ & $138 / 33.5 \%$ & $152 / 31.1 \%$ \\
\hline Acts younger than children his or her age & $403 / 98 \%$ & $5 / 1.2 \%$ & $3 / 0.8 \%$ \\
\hline Does not listen to rules & $303 / 73.7$ & $63 / 15.3 \%$ & $45 / 11 \%$ \\
\hline Does not show feelings & $399 / 97 \%$ & $5 / 1.2 \%$ & $7 / 1.7 \%$ \\
\hline Does not understand other's feelings & $318 / 77.3 \%$ & $12 / 2.9 \%$ & $81 / 19.8 \%$ \\
\hline Teases other & $382 / 92.9 \%$ & $7 / 1.7 \%$ & $22 / 5.4 \%$ \\
\hline Blames others for his or her troubles & $262 / 63.7 \%$ & $132 / 32.2 \%$ & $17 / 4.1 \%$ \\
\hline Takes things that do not belong to him/her & $325 / 79 \%$ & $32 / 7.7 \%$ & $54 / 13.3 \%$ \\
\hline Refuses to share & $63 / 15.3 \%$ & $121 / 29.4 \%$ & $7 / 1.7 \%$ \\
\hline
\end{tabular}

Abbreviations: HAART Highly Active Anti Retroviral Therapy

that care givers' mental distress has significant association with EBPs of children and adolescents with HIV/ AIDS. The findings of the current study also confirmed that mental distress can increase the odds of having EBPs by1.64 times among children and adolescents with HIV/AIDS This possible reason might be due to the fact that there is a possibility of displaying "Expressed
Emotion" towards children and adolescents and negligence to take care when they become psychologically distressed [42].

\section{Limitation of the study}

This study has some limitations. First, PSCL is a screening tool for EBPs and the diagnosis of EBPs never been 
Table 4 Bivariable and multivariable analysis of Emotional and Behavioral Problems among children and adolescent on HAART in West Gojjam Zone Public Hospitals, North West Ethiopia, 2018(N=411)

\begin{tabular}{|c|c|c|c|c|c|c|}
\hline \multirow[t]{2}{*}{ Variables } & \multirow[t]{2}{*}{ Categories } & \multicolumn{2}{|l|}{ EBPs status } & \multirow[t]{2}{*}{ COR(95\%Cl) } & \multirow[t]{2}{*}{$\mathrm{AOR}(95 \% \mathrm{Cl})$} & \multirow[t]{2}{*}{$P$-Value } \\
\hline & & Positive N (\%) & Negative N (\%) & & & \\
\hline \multirow[t]{3}{*}{ Age in years } & $5-9$ & $70(63.6)$ & $40(36.4)$ & $3.88(2.14-7.00)$ & $5.33(2.56,11.04)^{* * *}$ & 0.00 \\
\hline & $10-14$ & $81(38.4)$ & $130(61.6)$ & $1.38(0.82-2.33)$ & $1.95\left(1.08-3.55^{*}\right.$ & 0.03 \\
\hline & $15-18$ & $28(31.1)$ & $62(68.9)$ & 1.00 & 1.00 & \\
\hline \multirow[t]{2}{*}{ School attendance } & Attended & $137(40.9)$ & $198(59.1)$ & 1.00 & 1.00 & \\
\hline & Non attended & $42(55.3)$ & $34(44.7)$ & $1.79(1.08-2.95)$ & $0.61(0.31-1.18)$ & 0.14 \\
\hline \multirow[t]{4}{*}{ Caregiver's educational level } & College & $95(47.5)$ & $105(52.5)$ & 1.00 & 1.00 & \\
\hline & Secondary & $14(63.6)$ & $8(36.4)$ & $1.93(0.78-4.81)$ & $0.81(0.26-2.48)$ & 0.71 \\
\hline & Primary & $13(40.6)$ & $19(59.4)$ & $0.76(0.35-1.61)$ & $0.99(0.43-2.33)$ & 0.99 \\
\hline & Illiterate & $57(36.3)$ & $100(63.7)$ & $0.63(0.41-0.97)$ & $0.64(0.40-1.04)$ & 0.07 \\
\hline \multirow[t]{3}{*}{ Caregiver's relationship } & Parent & $135(39.6)$ & $206(60.4)$ & 1.00 & 1.00 & \\
\hline & Relative & $35(61.4)$ & $22(38.6)$ & $2.43(1.37-4.32)$ & $1.95(0.93-4.07)$ & 0.08 \\
\hline & Non-kin & $9(69.2)$ & $4(30.8)$ & $3.43(1.04,11.37)$ & $4.64(1.20-17.90)^{*}$ & 0.03 \\
\hline \multirow[t]{3}{*}{ Parental loss } & Both alive & $56(33.9)$ & $109(66.1)$ & 1.00 & 1.00 & \\
\hline & Single & $84(46.4)$ & $97(53.6)$ & $1.69(1.09-2.60)$ & $1.73(1.07-2.81)^{*}$ & 0.03 \\
\hline & Both died & $39(60.0)$ & $26(40.0)$ & $2.92(1.62-5.28)$ & $2.15(1.03-4.49)^{*}$ & 0.04 \\
\hline \multirow[t]{2}{*}{ HIV self disclosure status } & Disclosed & $104(36.1)$ & $184(63.9)$ & 1.00 & 1.00 & \\
\hline & Non disclosed & $75(60.98)$ & $48(39.02)$ & $2.76(1.79-4.27)$ & $1.99(1.16-3.41)^{* *}$ & 0.01 \\
\hline \multirow[t]{2}{*}{ Care-giver's mental distress } & Distressed & $87(50.6)$ & $85(49.4)$ & $1.64(1.10-2.43)$ & $1.64(1.04-2.57)^{*}$ & 0.03 \\
\hline & Not distressed & $92(38.5)$ & $147(61.5)$ & 1.00 & 1.00 & \\
\hline
\end{tabular}

Abbreviations: HAART Highly Active Anti Retroviral Therapy

${ }^{*} P$-value $<0.05,{ }^{* *} p<0.01,{ }^{* * *} p<0.001$

confirmed. This may overestimate the prevalence of EBPs. Second, the PSCL tool is not validated in Ethiopia. Third, when the child/adolescent had difficulty in answering questions, care givers participated on their child's behalf. This might not be consistent with what the child would have answered. Fourth, family monthly income was assessed simply by asking the estimated amount of money they earned every month. It would have been more accurate to use the wealth-index. Finally, the cross-sectional nature of the study might not show the direct cause and effect relationships of variables.

\section{Conclusion}

The prevalence of Emotional and Behavioral Problems is high among children and adolescents on HAART. Lower age, care giver's mental distress, non selfdisclosure status, having non-kin care giver and parental loss were variables significantly associated with EBPs. This demonstrates a need for the integration of Mental Health and Psycho Social Support (MHPSS) service with HIV/AIDS care. Moreover, disclosing their HIV sero status, providing care with kins/own parents and, prevention and treatment of care giver's mental distress are very crucial too.

\section{Additional file}

Additional file 1: English version questionnaire. (DOCX 19 kb)

\section{Abbreviations}

AIDS: Acquired Immune Deficiency Syndrome; AOR: Adjusted Odds Ratio; ART: Antiretroviral Therapy; Cl: Confidence Interval; COR: Crude Odd Ratio; EBP: Emotional and Behavioral Problems; FMOH: Federal Ministry of Health; HAART: Highly Active Antiretroviral Therapy; HIV: Human Immune Virus; MHPSS: Mental Health and Psycho Social Support; PLWHA: People Living with HIV/AIDS; PSCL: Pediatrics Symptomatology Check List; SPSS: Statistical package for social sciences; SRQ: Self Response Questionnaire

\section{Acknowledgements}

First, we would like to thank Addis Ababa University and Debre Tabor University for giving this opportunity. Second, we would like to forward our deepest gratitude to West Gojjam zonal health department staffs for their support in the completion of this research work. Finally, we are grateful to thank all the study participants for their willingness to participate and genuine response.

\section{Funding}

No specific fund is secured for this study.

\section{Availability of data and materials}

All the data included in the manuscript can be accessed from the corresponding author Demewoz Kefale upon request through an email address of demewozk@yahoo.com. 


\section{Authors' contributions}

$D K, A B$ and $Z M$ originated the idea and wrote the proposal, participated in data collection, analyzed the data and drafted the paper. ZB and SZ participated in analysis, interpretation and writing of the manuscript. All authors read and approved the final version of the manuscript.

\section{Ethics approval and consent to participate}

Ethical clearance was obtained from Addis Ababa University, College of Heath Science and supportive letter was secured from West Gojjam Zonal Health Department Office. Written assent was obtained from the care givers of each participant after brief explanation about the scope and objectives of the study prior to the interview. Personal identifiers such as name and phone numbers of the study participants never been recorded for the purpose of anonymity. The collected information was kept confidential and used only for the purpose of study.

\section{Consent for publication}

Not applicable.

\section{Competing interests}

The authors declare that they have no competing interests.

\section{Publisher's Note}

Springer Nature remains neutral with regard to jurisdictional claims in published maps and institutional affiliations.

\section{Author details}

${ }^{1}$ Department of Pediatrics and Child Health Nursing, College of Health Science, Debre Tabor University, Debre Tabor, Ethiopia. ${ }^{2}$ School of Nursing and Midwifery, College of Health Science, Addis Ababa University, Addis Ababa, Ethiopia. ${ }^{3}$ Department of Psychiatry, College of Health and Medical Science, Dilla University, Dilla, Ethiopia.

\section{Received: 18 December 2018 Accepted: 11 March 2019}

\section{Published online: 03 May 2019}

\section{References}

1. Challe S, Christopoulos S, Kull M, Meuleman L. Steering the povertyenvironment Nexus in Central Asia: a Metagovernance analysis of the poverty environment initiative (PEI). Dev Policy Rev. 2017;36(4):409-31.

2. Katherine Hutchinson M, Kahwa E, Waldron N, Hepburn Brown C, Hamilton $\mathrm{PI}$, Hewitt HH, et al. Jamaican mothers' influences of adolescent girls' sexual beliefs and behaviors. J Nurs Scholarsh. 2012;44(1):27-35.

3. Petersen I, Bhana A, Myeza N, Alicea S, John S, Holst H, et al. Psychosocial challenges and protective influences for socio-emotional coping of HIV+ adolescents in South Africa: a qualitative investigation. AIDS Care. 2010; 22(8):970-8

4. Biemba G, Macwangi M, Phiri B, Simon J. Zambia research situation analysis on orphans and other vulnerable children. Final Report Boston University Centre for Global Health and Development in collaboration with University of Zambia; 2010

5. Mavhu W, Berwick J, Chirawu P, Makamba M, Copas A, Dirawo J, et al. Enhancing psychosocial support for HIV positive adolescents in Harare, Zimbabwe. PloS one. 2013;8(7):e70254.

6. Pitorak H, Duffy MH, Sharer M. "There is no health without mental health": mental health and HIV service integration in Zimbabwe: situational analysis; 2012.

7. UNAIDS J. Global report: UNAIDS report on the global AIDS epidemic 2010. Geneva: UNAIDS; 2010

8. Giannattasio A, Officioso A, Continisio Gl, Griso G, Storace C, Coppini S, et al. Psychosocial issues in children and adolescents with HIV infection evaluated with a World Health Organization age-specific descriptor system. J Dev Behav Pediatr. 2011;32(1):52-5.

9. Abbas S, Ihle P, Adler J-B, Engel S, Günster C, Holtmann M, et al. Predictors of non-drug psychiatric/psychotherapeutic treatment in children and adolescents with mental or behavioural disorders. Eur Child Adolesc Psychiatry. 2017;26(4):433-44.

10. Scholte WF, Verduin F, van Lammeren A, Rutayisire T, Kamperman AM Psychometric properties and longitudinal validation of the self-reporting questionnaire (SRQ-20) in a Rwandan community setting: a validation study. BMC Med Res Methodol. 2011;11(1):116.
11. Pathak R, Sharma RC, Parvan U, Gupta B, Ojha RK, Goel N. Behavioural and emotional problems in school going adolescents. Australas Med J. 2011;4(1):15.

12. Idris IB. Emotional And Behavioural Problems Among Children: Issues and trends in Malaysia. Int J Public Health Res. 2017;7(2):829-35.

13. Coleman MC, Webber J. Emotional and behavioral disorders: theory and practice. Child Educ. 1996;70:279-82.

14. Egger HL, Angold A. Common emotional and behavioral disorders in preschool children: presentation, nosology, and epidemiology. J Child Psychol Psychiatry. 2006;47(3-4):313-37.

15. Dow DE, Turner EL, Shayo AM, Mmbaga B, Cunningham CK, O'Donnell K. Evaluating mental health difficulties and associated outcomes among HIVpositive adolescents in Tanzania. AIDS Care. 2016;28(7):825-33.

16. Fawzi MCS, Ng L, Kanyanganzi F, Kirk C, Bizimana J, Cyamatare F, et al. Mental Health and Antiretroviral Adherence Among Youth Living With HIV in Rwanda. Pediatrics. 2016;138(4):e20153235.

17. Nöstlinger C, Bartoli G, Gordillo V, Roberfroid D, Colebunders R. Children and adolescents living with HIV positive parents: emotional and behavioural problems. Vulnerable Children Youth Studies. 2006;1 (1):29-43.

18. Belfer ML. Child and adolescent mental disorders: the magnitude of the problem across the globe. J Child Psychol Psychiatry. 2008;49(3):226-36.

19. Kim MH, Mazenga AC, Yu X, Devandra A, Nguyen C, Ahmed S, et al. Factors associated with depression among adolescents living with HIV in Malawi. BMC Psychiatry. 2015;15(1):264.

20. Black MM, Jukes MC, Willoughby MT. Behavioural and emotional problems in preschool children. Lancet Psychiatry. 2017;4(2):89-90.

21. Abera M, Robbins JM, Tesfaye M. Parents' perception of child and adolescent mental health problems and their choice of treatment option in Southwest Ethiopia. Child Adolesc Psychiatry Ment Health. 2015;9(1):40.

22. Bankole KO, Bakare MO, Edet BE, Igwe MN, Ewa AU, Bankole IA, et al. Psychological complications associated with HIV/AIDS infection among children in south-South Nigeria, sub-Saharan Africa. Cogent Medicine. 2017:4(1):1372869.

23. Tadesse AW, Berhane Tsehay Y, Girma Belaineh B, Alemu YB. Behavioral and emotional problems among children aged 6-14 years on highly active antiretroviral therapy in Addis Ababa: a cross-sectional study. AIDS Care. 2012:24(11):1359-67.

24. Lowenthal E, Lawler K, Harari N, Moamogwe L, Masunge J, Masedi M, et al. Validation of the pediatric symptom checklist in HIV-infected Batswana. J Child Adolesc Ment Health. 2011;23(1):17-28.

25. Jellinek MS, Murphy JM, Little M, Pagano ME, Comer DM, Kelleher KJ. Use of the pediatric symptom checklist to screen for psychosocial problems in pediatric primary care: a national feasibility study. Arch Pediatr Adolesc Med. 1999;153(3):254-60.

26. Han DH, Woo J, Jeong JH, Hwang S, Chung U-S. The Korean version of the pediatric symptom checklist: psychometric properties in Korean schoolaged children. J Korean Med Sci. 2015;30(8):1167-74.

27. Joshi D, Tiwari MK, Kannan V, Dalal S, Mathai S. Emotional and behavioral disturbances in school going HIV positive children attending HIV clinic. Med J Armed Forces India. 2017;73(1):18-22.

28. Beusenberg M, Orley JH, Organization WH. A User's guide to the self reporting questionnaire (SRQ). Geneva: World Health Organization; 1994.

29. Mendoza R, Hernandez-Reif M, Castillo R, Burgos N, Zhang G, ShorPosner G. Behavioural symptoms of children with HIV infection living in the Dominican Republic. West Indian Med J. 2007;56(1):55-9.

30. Ruiseñor-Escudero H, Familiar I, Nakasujja N, Bangirana P, Opoka R, Giordani $B$, et al. Immunological correlates of behavioral problems in school-aged children living with HIV in Kayunga, Uganda. Global Mental Health. 2015;2.

31. Pastor PN, Reuben CA, Duran CR. Identifying Emotional and Behavioral Problems in Children Aged 4-17 Years: United States, 2001-2007. National Health Statistics Reports. Number 48. National Center for Health Statistics; 2012.

32. Monico L, Nobre-Lima L, Arraiol D, Rodrigues F, Cardeira H, editors. Emotional and behavioral problems in children and adolescents with hiv: a study with the youth self report and the child behaviour checklist. SGEM2014 Conference on Psychology and Psychiatry, Sociology and Healthcare, Education; 2014: Stef 92 Technology.

33. Jacobson JW. Prevalence of mental and behavioral disorders. Mental Health Intellectual Disabilities Aging Process. 2003:19:7-21. https://doi.org/10.1111/j. 1468-3148.2006.00293.x 
34. Tadesse B, Kebede D, Tegegne T, Alem A. Childhood behavioural disorders in Arnbo district, western Ethiopia. I. Prevalence estimates. Acta Psychiatrica Scandinavica. 1999;100:92-7.

35. Ashenafi Y, Kebede D, Desta M, Alem A. Prevalence of mental and behavioral disorders in children in Ethiopia. East Afr Med J. 2001;78(6):308-11.

36. Whetten K, Reif S, Whetten R, Murphy-McMillan LK. Trauma, mental health distrust, and stigma among HIV-positive persons: implications for effective care. Psychosom Med. 2008;70(5):531-8.

37. Krentz HB, Cosman I, Lee K, Ming JM, Gill MJ. Pill burden in HIV infection: 20 years of experience. Antivir Ther. 2012;17(5):833-40.

38. Organization WH. Guideline on HIV disclosure counselling for children up to 12 years of age. 2011.

39. Malee KM, Tassiopoulos K, Huo Y, Siberry G, Williams PL, Hazra R, et al. Mental health functioning among children and adolescents with perinatal HIV infection and perinatal HIV exposure. AIDS Care. 2011;23(12):1533-44.

40. Sanmaneechai O, Puthanakit T, Louthrenoo O, Sirisanthana V. Growth, developmental, and behavioral outcomes of HIV-affected preschool children in Thailand. J Med Assoc Thai. 2005;88(12):1873.

41. Puffer ES, Drabkin AS, Stashko AL, Broverman SA, Ogwang-Odhiambo RA, Sikkema KJ. Orphan status, HIV risk behavior, and mental health among adolescents in rural Kenya. J Pediatr Psychol. 2012;37(8):868-78.

42. Skeen S, Tomlinson M, Macedo A, Croome N, Sherr L. Mental health of carers of children affected by HIV attending community-based programmes in South Africa and Malawi. AIDS Care. 2014;26(sup1):S11-20.

43. Mellins CA, Malee KM. Understanding the mental health of youth living with perinatal HIV infection: lessons learned and current challenges. J Int AIDS Soc. 2013;16(1).

44. Sherr L, Cluver LD, Betancourt TS, Kellerman SE, Richter LM, Desmond C. Evidence of impact: health, psychological and social effects of adult HIV on children. Aids. 2014;28:S251-S9.

Ready to submit your research? Choose BMC and benefit from:

- fast, convenient online submission

- thorough peer review by experienced researchers in your field

- rapid publication on acceptance

- support for research data, including large and complex data types

- gold Open Access which fosters wider collaboration and increased citations

- maximum visibility for your research: over $100 \mathrm{M}$ website views per year

At $\mathrm{BMC}$, research is always in progress.

Learn more biomedcentral.com/submissions 